\begin{tabular}{|c|c|}
\hline & $\begin{array}{l}\text { International Journal of Trend in Scientific } \\
\text { Research and Development (IJTSRD) }\end{array}$ \\
\hline 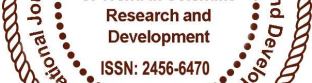 & International Open Access Journal \\
\hline 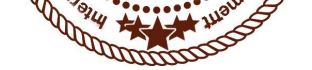 & ISSN No: 2456 - 6470 | www.ijtsrd.com | Volume - 2 | Issue - 2 \\
\hline
\end{tabular}

\title{
An analytical framework on deceptive Advertising with reference to Hyderabad City, Telangana State, India
}

\author{
Mr. Mohammad Sirajuddin \\ Assistant Professor, Department of Management, \\ CMR College of Engineering and Technology, \\ Kandlakoya, Medchal, JNTUH, India
}

\author{
Mr. Ch. B. V. L. Sudheer \\ Assistant Professor, Department of \\ Management,CMR College of Engineering and \\ Technology, Kandlakoya, Medchal, JNTUH, India
}

\section{ABSTRACT}

This research has documented that consumers can be highly vulnerable to misleading advertising claims that lead them to acquire false information, form misperceptions, as the problems in consumer world are increasing very fast and most of the advertising agencies and manufacturing firms $\mid$ waiting such opportunities to lure the consumers through deceptions consumer is already involved in searching solutions and become involved in consumptive behaviors to their detriment. The experimental studies, in particular, explore the possible causal relationships between claims and consumer psychological or behavioral responses to map the claims many a times the mapping goes in a favor of consumers as they feel that the claims that are raised by the companies goes downward leading to dissatisfaction by the consumer.

Keywords: Advertising, Consumer Behavior, and Consumer Sentiment

know to the people. In this effort, advertisements are filled with tall claims that are sometimes too hard to believe.

Fairness cream ads try to depict that only a fair person has a good chance to succeed in life. An American will call it downright racism, but it is perfectly fine in India. Energy drinks are depicted as if they give superhuman powers to the consumer. Some even suggest that their children will not grow up properly if they do not consume their chocolate-flavored milk powder or the addition of these powers help in absorbing more of calcium.

The worst culprits are celebrity endorsements. The celebrities never use the product, but they appear in the advertisements of products that promises consumers the same skin \& hair of the celebrity. In all cases, the glow on the skin of the actress is due to the skills of the makeup artist.

Coming to the lower levels of print ads, many people would have observed the blatant lie in the "Before \& After" ads for fat-loss, hair loss, tooth loss, etc. The use of computer graphics is obvious to create these ads. Then there are play with words like "Up to $50 \%$ sale", or "Just 3 flats remaining", or "Free, but conditions apply". Why are the applied conditions typed in so miniscule font?

We would be conducting an empirical research to test $\&$ evaluate the hypotheses and use a tool like 
questionnaires to quantify \& qualify the responses. The questionnaire will contain both open-ended as well as close-ended questions. The responses would be coded for purpose of quantitative analysis. A chisquare test would be done to form a logical conclusion.

The research will aid marketers to understand the impact advertisements have on consumer buying decisions. It would give a suggestion, what actually entices a customer to choose a particular product. Do consumers have a good memory to recollect the claims that the advertisements have made or do they shop on impulse? What are the other factors that lead a customer to buy a product? And finally, can advertisers still sell their products based on pure facts, or do they need the added chutzpah of tall claims to push their products forward?

\section{Literature Review}

Many alleged deceptive claims nowadays are implicitly manipulative rather than outright false (Mazis, 2005; Shanahan \& Hopkins, 2007). The literature has documented solid evidence of deception by implication. For example, in a study about attribute claims of ibuprofen based brands, Burke et al. (1988) examine four types of claims: no attribute information, truth, expansion implications, and inconspicuous qualification implications. They find that expansion and inconspicuous qualification implications increase respondents ${ }^{\text {ee }}$ false attribute beliefs about headache pain relief, side effects, and speed of relief. In another study (Pechmann 1996), a company claims that it charges the lowest rate for a particular service but does not mention that it charges more than competitors for other required services. Due to erroneous inferences, respondents tend to believe that this company has the lowest overall price. Erroneous inferences can expand beyond the claimed attributes. Barona and Miniard (1999) expose respondents to a partially comparative advertisement containing a combination of comparative and noncomparative claims. They find a "copy x copy" interaction: the processing of one claim affects beliefs about other claims in the same advertisement. In this process, respondents acquire the belief that the advertised brand is better than the competitor, not only in terms of the attributes featured in the comparative claim, but also those in the noncomparative claims. Theoretically, erroneous inferences occur due to psychological mechanisms such as pragmatic implication, logical consistency, and informational influence (Hastak \& Mazis, in press). In essence, consumers have certain default understandings about the proper usages of certain words, semantics, symbols, and expressions (Harris, 2009). Such lay theories are not perfectly accurate or logical, but consumers often rely on such easily accessible schemata to comprehend an advertising claim. Deceptive claims take advantage of such presuppositions without clarifying the exact meanings in specific contexts. For instance, a package label that claims " $50 \%$ more recycled content than before" suggests an increase of recycled goods by one half; however, the manufacturer's total increase of recycled content has only improved from $2 \%$ to $3 \%$. Although the message is technically true, the FTC rules this claim deceptive because the label can create false impressions (Federal Trade Commission, 2010).

\section{Methodology}

\subsection{Research Questions}

We have formulated two hypotheses that we will be testing in the research. The first hypothesis to test is there a relationship between deceptive advertising and consumer purchase.

Second hypothesis that we will be testing is whether there is any relationship between age and gender difference and susceptibility to deceptive advertising

\subsection{Research Design}

The type of study for this paper is descriptive (Under the descriptive study technique the statistical method has been used. Here the researcher must design their studies to give as much evidence as possible for reflecting the cause and effect relationships from the data collected through the ,survey ${ }^{\text {ee }}$ technique. The designs of such studies should be planned with the type of required analysis already in mind).

For our research we have tried to get a good representation of the sample by diversifying our sample collection. We did a stratified random sampling with a sample size of 100 respondents from the age $22-42$ both male and female at various locations in Hyderabad.

We used a questionnaire for our data collection which consisted of both open and closed ended questions. 
The period of the study was from $1^{\text {st }}$ December 2017 to $31^{\text {st }}$ December 2017. Simple mathematical calculations and chi-square test and ANOVA were used for the purpose of data analysis and interpretation.

\subsection{Limitations of the study}

One of the major limitations faced by us was the time. Another constraint which we felt was the ignorance of the selected subjects. Lastly we cannot judge whether the respondents gave us a completely true reply.

\section{Results and Discussion:}

H0: There is no relationship between deceptive advertising and buying

\section{H1: There is relationship between deceptive advertising and buying}

H0: There is no relationship between age, gender
and susceptibility to deceptive advertising

H1: There is a relationship between age, gender and susceptibility to deceptive advertising

Table 4b: Number and Type of Deceptive Advertisements on Television

\begin{tabular}{|c|c|c|c|}
\hline $\begin{array}{l}\text { Deceptive } \\
\text { Statement }\end{array}$ & Claim & $\%$ & $\%$ \\
\hline & 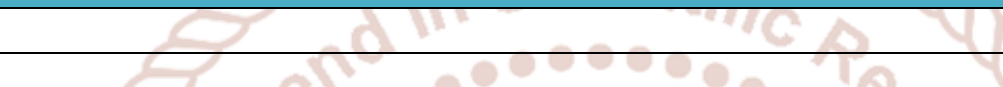 & $\begin{array}{l}\text { Unique } \\
\text { Ads }\end{array}$ & Appearances \\
\hline Red Flag 1 & $\begin{array}{l}\text { Product will cause weight loss of more than } 2 \text { pounds per } \\
\text { week for more than } 1 \text { month without diet exercise }\end{array}$ & 1.81 & .30 \\
\hline Red Flag 2 & $\begin{array}{l}\text { Product will cause substantial weight loss no matter what } \\
\text { or how much consumer eats }\end{array}$ & 2.10 & .0006 \\
\hline Red Flag 3 & $\begin{array}{l}\text { Product will cause permanent weight loss, even when the } \\
\text { consumer stops using the products }\end{array}$ & 5.42 & 5.48 \\
\hline Red Flag 4 & $\begin{array}{l}\text { Product blocks absorption of fat or calories to enable users } \\
\text { to lose substantial weight }\end{array}$ & 1.59 & .0006 \\
\hline Red Flag 5 & $\begin{array}{l}\text { Product safely enables consumers to lose greater than three } \\
\text { pounds per week for more than four weeks }\end{array}$ & 10.05 & 9.65 \\
\hline Red Flag 6 & Product will cause substantial weight loss for all users & .94 & 1.38 \\
\hline Red Flag 7 & $\begin{array}{l}\text { Product will cause substantial weight loss by wearing it on } \\
\text { the body or rubbing it onto the skin }\end{array}$ & .29 & .0001 \\
\hline One or more & Ads at least one of the preceding claims & 17.86 & 16.09 \\
\hline
\end{tabular}

From the responses received and by conducting a chisquare test on the first hypothesis, it was observed that there is a strong relationship between misleading ads and consumer purchase. This means that the misleading ads have a strong impact on the consumer buying behavior of the consumers and are major determinant for the purchase decision. The consumers accept the information being provided in the advertisement as true and the buyer suffer dissonance if the product does not function as advertised. From the responses received and by conducting a chi-square test on the second hypothesis, it can be inferred that misleading ad affects consumers mind differently based on the age and gender. The younger age group was more susceptible to the misleading ads and this was the same age group that indulges in impulsive purchases. It was also found out that females make a more informed decision prior to their purchase, but their source of information is usually the advertisements or word-of-mouth information from peers or other reference group.

\section{Conclusions and Recommendations}

False advertising, in the most blatant of contexts, is illegal in most countries. However, advertisers still find ways to deceive consumers in ways that are legal, or technically illegal but unenforceable. A classic example is that of the cigarette ad that shows a freespirited confident cowboy on his horse galloping through the rough terrain, catching wild cattle without breaking a sweat. In reality, cigarette smoking is a purely wasteful habit, with no beneficial or nutritional value. It is highly addictive and a cause of various deadly illnesses. 
International Journal of Trend in Scientific Research and Development (IJTSRD) ISSN: 2456-6470

Marketers have just one aim in mind - sell as much as possible to as many as possible. They do not mind using unethical practices. For them, reaching the end is more important than the means.
Our research clearly shows that misleading advertisements that make tall claims do not make an impact on the buying behavior of the consumers. There are certain wise consumers

Table 7: Consumption of OTC Weight Loss Products as a Function of Exposure to Ads and Deceptive Statements, Women

\begin{tabular}{|c|c|c|c|}
\hline & Women & Women & Women \\
\hline & & & Cosmo-Glamour- \\
\hline & & & Soap Operas \\
\hline & $\mathrm{N}=26,951$ & $\mathrm{~N}=26,951$ & $\mathrm{~N}=8,128$ \\
\hline OTC Ads/ 100 & $\mathrm{ME}=.0171$ & $\mathrm{ME}=.0113$ & $\mathrm{ME}=.0179$ \\
\hline & $\mathrm{p}=.001$ & $\mathrm{p}=.005$ & $\mathrm{p}=.009$ \\
\hline OTC Deceptive Statements / 100 & $\mathrm{ME}=-.0326$ & $\mathrm{ME}=-.0238$ & $\mathrm{ME}=-.0372$ \\
\hline & $p=.008$ & $\mathrm{p}=.051$ & $\mathrm{p}=.086$ \\
\hline Rx Ads / 100 & $\mathrm{ME}=.0131$ & C7f $\mathrm{ME}=.0099$ & $\mathrm{ME}=-.0091$ \\
\hline & $\mathrm{p}=.222$ & $\mathrm{p}=.361$ & $p=.619$ \\
\hline Demographic variables & Yes & Yes 3 & Yes \\
\hline 200 & $\|\cup\| \cup \|$ & 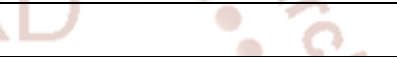 & \\
\hline Socioeconomic variables & Yes & Yes & Yes \\
\hline $2+8$ & & tront 0 & \\
\hline Overweight / obesity variables 0 & IreYes III S & GlentiYes & Yes \\
\hline 820 & & 8 & \\
\hline Magazine, TV intensity variable & Yes & Yes & Yes \\
\hline $1 / 200$ & DeVelOp| & nent & 2 \\
\hline Magazine, TV category variables & & Yes & \\
\hline
\end{tabular}

Table 8: Consumption of OTC Weight Loss Products as a Function of Exposure to Ads and Deceptive Statements, Men

\begin{tabular}{|c|c|c|}
\hline & Men & Men \\
\hline & $\mathrm{N}=14,275$ & $\mathrm{~N}=14,275$ \\
\hline OTC Ads/ 100 & $\mathrm{ME}=.0091$ & $\mathrm{ME}=.0026$ \\
\hline & $\mathrm{p}=.085$ & $\mathrm{p}=.633$ \\
\hline OTC Deceptive Statements / 100 & $\mathrm{ME}=-.0190$ & $\mathrm{p}=.453$ \\
\hline Rx Ads / 100 & $\mathrm{p}=.241$ & $\mathrm{ME}=.0037$ \\
\hline & $\mathrm{ME}=.0072$ & $\mathrm{p}=.837$ \\
\hline Demographic variables & $\mathrm{p}=.685$ & Yes \\
\hline Socioeconomic variables & Yes & Yes \\
\hline Overweight / obesity variables & Yes & Yes \\
\hline Magazine, TV intensity variable & Yes & Yes \\
\hline Magazine, TV category variables & Yes & Yes \\
\hline
\end{tabular}


International Journal of Trend in Scientific Research and Development (IJTSRD) ISSN: 2456-6470

Table 9: Consumption of OTC Weight Loss Products as a Function of Exposure to Non-Deceptive Ads and Deceptive Ads, Women

\begin{tabular}{|c|c|c|c|}
\hline & Women & Women & Women \\
\hline & & & Cosmo-Glamour- \\
\hline & & & Soap Operas \\
\hline & $\mathrm{N}=26,951$ & $\mathrm{~N}=26,951$ & $\mathrm{~N}=8,128$ \\
\hline OTC Nondeceptive Ads/ 100 & $\mathrm{ME}=.0173$ & $\mathrm{ME}=.0116$ & $\mathrm{ME}=.0168$ \\
\hline & $\mathrm{p}=.001$ & $\mathrm{p}=.004$ & $\mathrm{p}=.015$ \\
\hline OTC Deceptive Ads / 100 & $\mathrm{ME}=-.0148$ & $\mathrm{ME}=-.0124$ & $\mathrm{ME}=-.0153$ \\
\hline & $\mathrm{p}=.084$ & $\mathrm{p}=.150$ & $\mathrm{p}=.314$ \\
\hline Rx Ads / 100 & $\mathrm{ME}=.0140$ & $\mathrm{ME}=.0106$ & $\mathrm{ME}=.0110$ \\
\hline & $\mathrm{p}=.187$ & $\mathrm{p}=.327$ & $\mathrm{p}=.545$ \\
\hline Demogranhic variables & Yes $2 \mathrm{YCH}$ & Yes & Voc \\
\hline 20 & 140000 & & 100 \\
\hline Socioeconomic variables & Yes & Yes & Yes \\
\hline 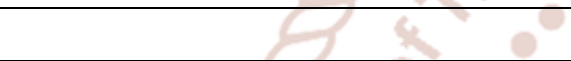 & $1-\mathrm{OA}$ & 20 & ( \\
\hline Overweight / obesity variables & Yes & Yes & Yes \\
\hline 800 & & & \\
\hline Magazine, TV intensity variable & Yes & Yes & Yes \\
\hline $4=01$ & Trend in s & cientific & 4 \\
\hline Magazine, TV category variables & & Yes & 2 \\
\hline 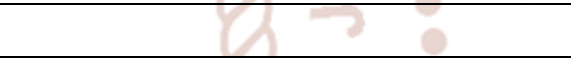 & & & \\
\hline
\end{tabular}

Who go by the fact, but there is a huge group of consumers that falls for the claims presented in the advertisement.

But, as they, with age comes wisdom. Our second hypothesis shows that the aged group of consumers is able to identify the misleading claims in the advertisements and is not easily influenced. The younger generation is easily led in to believing the claims. Therefore, most of the products in these advertisements tend to target the youth.

There are laws against the misleading advertisements, but marketers will always find a way out. They know where the Achilles Heel of the consumer lies and they hit them with the right tone, emotions and claims in their advertisements.

Therefore, it is time for the governing agencies to enforce stronger laws to reprimand anyone involved in a proven misleading advertisement. There is also a call for watchdog agencies to scientifically study and analyze advertisements to validate their claims.
Customers must be encouraged to come forth with products that did not deliver as promised and the results should be made known in public. Marketers should also realize that false information does not always stay hidden. They should thrive for ethical practices in advertisements and the same agencies should be awarded for being the beacon in providing true and accurate information to the consumers.

So, next time you pick a chips packet that claims zero cholesterol; think twice before falling for it. The seller has least concern for your health. He just wants to ensure that his chips are sold and the money keeps rolling in.

\section{Conclusions and Recommendations}

False advertising, in the most blatant of contexts, is illegal in most countries. However, advertisers still find ways to deceive consumers in ways that are legal, or technically illegal but unenforceable. A classic example is that of the cigarette ad that shows a freespirited confident cowboy on his horse galloping 
through the rough terrain, catching wild cattle without breaking a sweat. In reality, cigarette smoking is a purely wasteful habit, with no beneficial or nutritional value. It is highly addictive and a cause of various deadly illnesses.

Marketers have just one aim in mind - sell as much as possible to as many as possible. They do not mind using unethical practices. For them, reaching the end is more important than the means.

Our research clearly shows that misleading advertisements that make tall claims do not make an impact on the buying behavior of the consumers. There are certain wise consumers

\section{References}

1. Barone M.J., and Miniard P.W., 1999, How and When Factual Ad Claims Mislead Consumers: Examining the Deceptive Consequences of Copy $\mathrm{x}$ Copy Interactions for Partial Comparative Advertisements, Journal of Marketing Research, 2, $10-16$.

2. Burke, R. J., 1988, some antecedents and consequences of work-family conflict. Journal of Social Behavior and Personality, 3, 287-302.

3. Federal Trade Commission Act, 2010, Section 5 of the FTC Act (Declares unfair or deceptive acts or practices unlawful). Section 12 (Specifically prohibits false ads likely to induce the purchase of food, drugs, devices or cosmetics). Section 15 (Defines a false ad for purposes of Section 12 as one which is "misleading in a material respect).

4. Harris, R., 2009, Speech and Writing. In Olson, D. and Torrance, N. (eds.) The Cambridge Handbook of Literacy. 3, $47-51$

5. Hastak M., and Mazis M., 2005, Consumer perceptions of health claims in advertisements and on food labels. Journal of Consumer Affairs, 3, 11-24.

6. Pechmann, C., 1996, Do Consumers Overgeneralize One-sided Comparative Price Claims and Are More Stringent Regulations Needed? Journal of Marketing Research, 33, 150162.

7. Shanahan, K. J. and C. D. Hopkins, 2007, Truths, Half-Truths, and Deception: Perceived Social Responsibility and Intent to Donate for a Nonprofit Using Implicature, Truth, and Duplicity in Print Advertising. Journal of Advertising, 2, 3348. 